\title{
EFFECT OF SALES PROMOTION ON CUSTOMER PATROANGE OF ALCOHOLIC BEVERAGES (A STUDY OF CUSTOMERS OF ALCOHOLIC BEVERAGES IN AGUATA LGA)
}

\author{
Emma Ezenyilimba, Ph.D, \\ Department of Marketing, Nnamdi Azikiwe University Awka,E-mail: \\ ezenyilimbaem@yahoo.com, Phone: 08064410089 \\ Mbah, Chris Chukwuemeka, Ph.D. \\ Department of Marketing, Faculty of Management Sciences \\ Enugu State University of Science and Technology \\ Eze, Jude Obinna \\ Department of Marketing, Faculty of Management Sciences \\ Enugu State University of Science and Technology
}

\begin{abstract}
This study focused on the effect of sales promotion on customer patronage, of alcoholic beverages (A study of Consumer of Alcoholic Beverages in Aguata LGA). The widespread use of sales promotion has sparked considerable interest and debate over their effectiveness. Critics argue that sales promotions are ineffective as they make customers prone to promotion resulting in market share losses in the long run. However, other researchers have shown that sales promotions lead to real increases in sales and profits. Despite this discrepancy, very little is understood about sales promotion, especially with regards to how consumers respond to the various sales promotional strategies used by marketers. The main objective of the study is to determine the effect of sales promotion on consumer patronage. The specific objectives are to ascertain the effect of contest on customer patronage and to ascertain the effect of contest on customer patronage of alcoholic beverages.A survey research design was employed. The study made use of 115 respondents. Data was analyzed using Multiple Regression Analysis. The findings revealed that both dependent and independent variables (price, pack, contest and coupons) had significant effect on customer patronage. Finally, the study concluded that sales promotion has significant effect on customer patronage of alcoholic beverages. Based on the results of the study and conclusions, the following recommendations are made: In as much as sales promotion is a key element in the advancement of Brewer industry, tools selected should be sustained overtime while being flexible due to economic instability so as to avoid downward fluctuations in their profit margin.
\end{abstract}

Keywords:Sales Promotion, Customer Patroange of Alcoholic Beverages

\section{INTRODUCTION}

The business environment has become very competitive in the $21^{\text {st }}$ century. The environment is very complex and consumer preferences keep changing because of low switching cost in the market. In addition, the increased competition in the fast moving consumer product industry, particularly the beverage industry market has worsened the fight for customers, thus making survival difficult. Many new players have joined the market, worsening the already competitive market structure. 
However, the initial failure of many of these fast moving consumer product companies to understand the relevance of promotion made their survival difficult but currently almost every firm seeks to increase the sales of its product through an effective promotional tool. Promotion has always been a part of the industrial marketing process and is the preferred tool used to reach customers (Schultz, 2009) thus, allocation of the marketing budget goes hand in hand with promotional budget indicating importance of the latter (Blattberg and Neslin, 2009). In this era of global competition, firms in the manufacturing sectors uses various dimensions of sales promotion such as consumer sales promotion, trade promotion and salesforce to influence consumer's behaviour and increases sales.

The alcoholic beverage industries are not left out. Beer companies spend approximately $\$ 70$ billion annually on promotions Forbes, (2011). Blattberg and Neslin (2009) reported that between 2008 and 2013 the proportion of marketing budget spent on promotions was more than $70 \%$ in the United States of America. This increase is based on the fact that promotional spending has a large, measurable and immediate effect on brand sales.

In Nigeria a number of companies are engaged in production or importation of alcoholic drinks. For example would include the Nigeria Breweries, Consolidated Breweries Limited, Premium etc. these companies constantly promote their products using different promotional media and tools to influence consumer purchase decision. However, consumers tend to look for the "best one" and that's why their influctuating mind may switch on to new brands with a simple stimulus. In this case an extra incentive can be added to a product by different promotional activities (Blattberg and Neslin, 2009).

Among the various promotional tools $t$ has been found that sales promotion is one which stimulates quick and large purchases in a limited period of time (Mela, Gupta, \& Lehman, 2017).

Sales promotion on its own, can be defined as a marketing activities that adds to the basic value proposition behind a product (i.e getting more for less) for a limited time in order to stimulate consumer purchasing, selling effectiveness or effort of sales force (Aderemi, 2013). Sales promotion includes tools for consumer promotion, trade promotion ad sales-force promotion. For the purpose of this study, consumer promotions which are those efforts aimed at influencing the trial consumer will be looked into majorly. Thus is because they are promotions offered by manufacturers directly to consumers (Blattberg and Neslin, 2009). Mbaga (2016) indicated that consumer promotion tools have a huge impact on consumer patronage behaviour during any competition. However, Esfahani and Jafarzadeh (2012) found that psychological variables have a significant relationship with sales promotion; therefore they cocluded that there is no significant relationship between impulsive behaviour and sales promotion. Moreover, previous studies suggest that different market segments and consumer profiles react differently towards sales promotion. Several reasons for the variations in effectiveness were suggested, including demographic, cultural and ethnic differences, the value and timing of promotional offerings, as well as the type of product or service promoted (Aliawadi, Beauchamp, Donthu, Gauri \& Shankar, 2009).

This research work therefore, tries to investigate the effect of sales promotion on customer patronage of alcohol beverages. This will be achieved by looking into some consumer promotional tools like price pack, contests and coupons in order to determine their effect on consumer patronage of alcoholic beverages.

\subsection{Statement of the Problem}

The widespread use of consumer promotion tools has sparked considerable interest and debate over their effectiveness. Critics argue that consumer sales are ineffective as they make consumers more promotion prone, resulting in market share losses in the long run (Esfahani and Jafarzadeh (2012). However, other researchers have shown that consumer sales 
promotion lead to real increases in sales and profit (Mbaga, 2016). This discrepancy suggests that there are conditions and factors that can influence the effectiveness of sales promotion. For instance, it has been shown that customer sales promotions are among effective when they provide benefits that are congruent with those Nigerian consumers and their; purchase behaviour, especially with regards to how their respond to the various sales promotional strategies used by marketers of alcoholic beverages.

Furthermore, some manufacturing firms especially those operating in the brewery industries face high competition in the marketing of their products. Management of these firms faces the problems of customs switching over to competing fir due to ineffective sales promotional tools. There are also complaints of misapplication of sales promotional tools such as price pack, and coupons and ineffective use if contest in the promotion of a product (Esfahani and Jafarzadeh 2012). It is therefore doubtful if consumer sales promotion has much positive impact on customer patronage.

Furthermore, despite the number of researches on the effect of sales promotion, limited studies from African perspective have been done on the effect of sales promotion on customer patronage this study attempt to fill the gap by studying the effect of some dimensions of consumer sales promotion on customer patronage of alcoholic beverages.

\subsection{Objective Study}

The main objective of the study is to determine the effect of sales promotion on customer patronage of alcoholic beverages

1. To determine the effect of price packs on customer patronage of alcoholic beverages.

2. To ascertain the effect of contest on customer patronage of alcoholic beverages.

\subsection{Research Questions}

1. What is the effect of price on customer patronage of alcoholic beverages?

2. What is the effect of contest on customer patronage of alcoholic beverages?

\subsection{Research Hypotheses}

1. Ho: There is no significant effect of price pack on customer patronage of alcoholic beverages.

Hi: There is significant effect of price pack on customer patronage of alcoholic beverages.

2. Ho: There is no significant effect of contest on customer's patronage of alcoholic beverages.

Hi: There is a significant effect of contest on customer patronage of alcoholic beverages.

\section{Review of Related Literature}

\subsection{Conceptual Review}

\subsubsection{Concept of sales promotion}

It is necessary to first understand the concept of promotion. Promotion is defined as all activities undertaken to communicate and promote products or services to the target market. These activities include advertising, public relations, personal selling, sales promotion, exhibitions, brochures and demonstrations etc (Mbaga, 2016). Accrding to Kotler and Armstrong (2008) promotion is important to communicate customer value by creating awareness of the product existence and characteristics. Promotion informs customers on the products availability in the market.

According to Agbonifoh, Nnolim \& Nkamnebe, (2007), sales promotion is a direct inducement which offers an extra value or incentive for product to the sales force, 
distributors, or the ultimate consumers. With this we realize that sales promotion should be directed to the sales force, middlemen and the ultimate consumer. Sales promotion includes tools for consumer promotion (for example samples, coupons, prize, cash refund, price pack, warranties, demonstrations, contest); trade promotion (for example buying allowances, free goods, merchandise allowances, co-operative advertising, advertising and display allowances, dealer sales contests); and sales-force promotion (for example bonuses, contests, sales rallies).

Mkanda, M (2009) defined sales promotion as to consist of a collection of incentives, tools, mostly short designed to stimulate quicker or greater purchase of a particular product or service by consumers or trade. Sales promotion also consists of a collection of incentives, tools, mostly short term designed to stimulate quicker or greater purchase of a particular product or service by consumers or trade (Kotler and Keller 2006). Sales promotion also refers to any extra incentive manufacturers, retailers, and even not-for-profit organizations use that could serve to change a brand's perceived price or value temporarily (Shimp, 2010). For examples many offers in the markets notice such as promotion whereby discount is provided up to $50 \%$ and many other schemes are designed to attract customers to buy certain products. All these re incentives offered by manufacturers or dealers to increase the sales of their goods; These incentives may be in the form of free samples, gifts, discount coupons, demonstrations, show, and contests and among others. All these measures normally motivate the customers to buy more and thus, it increases sales of the product.

\subsubsection{Trade Promotion Tools}

- $\quad$ Trade allowances: They are short term special allowances, discounts or deals granted to retailers as an incentive to stock features or in some way participate in the cooperative promotion (Boone and Kurtz, 2004).

- Trade Contest: A trade contest typically associate price sales $f$ the sponsor's products. As in consumer contest, trade contest generates interest which makes them useful for motivation retailers. Effective trade contest should be periodically rather than all the time. Otherwise, they lose their motivation/potential.

Buy-back Scheme: It involves the manufacture agreeing to buy back their products which the middle men were not able to sell at a stated period. The scheme is most popular in newspaper houses where publishers accept to pay back published newspapers that are remained on sold and are returned to them within specific deadline. This encourage dealer to stock new products and it also brings about a wide exposure of products to dealers.

\subsubsection{Customer Patronage}

Experience shows that defining and measuring patronage is a difficult task. Attitude and actual usage has been used as measures of customer patronages (Ogwo and Igwe 2012). Dick and Basu (1994) precisely suggested that favorable attitude and repeat purchase were prerequisites to defining patronage.

\subsubsection{Consumer Patronage Behvaiour}

The customer is as old as business. The sole purpose of every business is to "Create Custoner". According to Drucker, (1973) as cited in Ogwo and Igwe (2012) opined that the only economic and social justification of any business existence to create customer satisfaction. The importance of the customer and customer patronage is so germane. It includes financial and non-financial dimensions. Various studies have been carried out on what influence or impacts on level of customer patronage. They include firm's capacity, product or services attributes, economic situation, political forces, social and psychological 
factors, situational, competition, marketing mix programs (Schiffman and Kanuk 2009 as cited in Ogwo and Igwe, 212; Kotler and Killer 2006). Intention to use is defined as a specific desire to continue relationship with a service provider (Czepiel and Culmore, 1987 as cited in Ogwo and Igwe, 2012).

Attitudinal measures have an advantage over behavioral measures (actual or repeat patronage) in that they can provide understanding of the factors associated with the development and modification of patronage (Oiva, Oliver and MacMiliaqn, 1992). Fishbin and Ajen (19975) argue that attitudes are functionally related to behavioural intentions, which predict behaviour. A person's intention to behave in a certain way is contingent upon the attitude toward performing the behaviour in question and the social pressure on him/her to behave in that way (subjective norm). This suggests that attitudes and subjective norms differ according to the person involved and behavioral context. Theory of Planned Behaviour (TPB), which is an extension of Theory of Reasoned Action (TRA), has introduced another factor that affects behavioural intention, which is the perceived behavioral control. Control beliefs and perceived power are the main construct of perceived behavioral control (Mackenzie \& Jurs, 1993 as cited in Ogwo \& Igwe, 2012). Consumers vary in their commitment to attitude; the degree of commitment relates to their level of involvement with the attitude object. This commitment ranges from inertia to a strong emotional passion. Commitment might be based on customer's intentions as want, expectation, plans for the future (Ogwo \& Igwe 2012).

\subsection{Theoretical Framework}

(a) Theory of Push and Pull

There are many theories on this study starting from the theory of push and pull of promotional mix, all marketing promotion activities, including advertising, sales promotion, public relations and personal selling, fall into one of these categories. The push strategy concentrates promotional activity on distribution channels. In other words, the sales force pushes the product to wholesalers, who promote it to their retailer network, which then puts the products in a retail store for consumers to see and purchase (e.g end-aisle display of unknown products).

The pull strategy on the other hand, relies heavily on marketing communication to create awareness and desire, thus pulling consumers into a store to purchase products. Both of these theories have strengths and weakness, ideally a combination of two approaches is used to both pull and push demand.

This theory is relevant to this study in the sense that the brewery industries that use the above theory/strategy will not only creates, persuade customers to patronize their products but also will always retain and maintain customer - producer relationship.

\subsection{Empirical Literature Review}

Sandra (2005) used a series of focus groups in three different locations with young people aged 16-25 years, separated by age and gender, with a total of 85 participants in the study of the effects of point of sales promotions on the alcohol purchasing behavior of young people in metropolitan, regional and rural Australia. Participants were asked questions about their recollection of various POS promotions and the effect of these promotions on their alcohol purchasing and consumption behaviour. The majority of participants indicated a strong link between POS promotions and alcohol purchasing and consumption behaviour. A majority of participants demonstrated a strong recall of previous promotions and almost all participants indicated they had been influenced to buy more or a particular brand of alcohol because of a promotion. Specifically, the result of the study indicate that POS promotions involving price 
or volume discounts have a strong impact on young people, and are particularly effective in encouraging the purchase of increase volumes of alcohol.

Ripon (2007) in the study the effects of sales promotion and advertising on consumers purchase behaviour reported that sales promotion is most effective on the consumers who travel through the peripheral route and it can lead the consumers mind to brand switching. This study also found that sales promotion and advertising is much more effective in low involvement category products where a simple promotional signal can lead to consumers to buy a product. This study also suggests to the marketers to be aware of the new or unknown product, as sales promotion could have strong negative effects on consumer's internal price reference and perceived quality. This work also highlights the importance of integrating the advertising with different promotional activities to improve the growth of sales of a product. Kwame (2013) in the study titled "does sales promotion influence buyer behaviour", identified the sem'anhyia duck bar soap sales promotion mechanisms adopted and determined how the sales promotion mechanisms affected the behaviour of young consumers. Apart from adult buyers, young consumers who are Senior High School (SHS) students in Ghana, often buy personal care products especially soap personally for their use at school. The study found that sales promotion has influenced many young consumes to purchase the product.

Makanda (2009) analyzed the consumer buying behaviours of Carbonated Soft Drinks in the Tanzanian market. Five hypotheses were empirically tested and the results showed that there is a significant negative relationship between the price of the pack and the choice of brand of carbonated soft drinks. Regarding quality, the result revealed that the perceived quality of the product negatively influenced the decision to purchase a carbonated soft drinks brand. The negative correlation might result from the fact that consumers often judge the quality of the products on the basis of variety of information cues that they associate with products.

\subsection{Researchers Theoretical Framework Independent Variables}

\section{Dependent Variables}

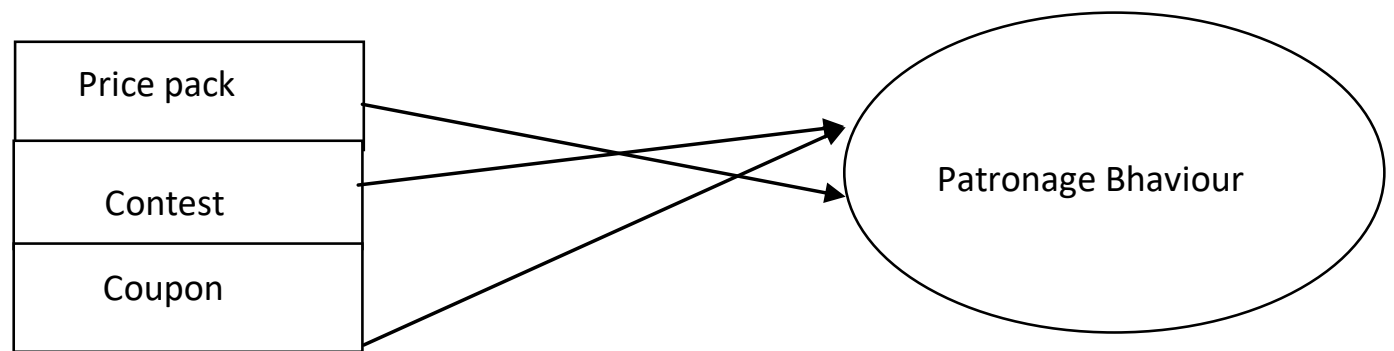

Source: Theoretical Framework by the Researcher.

\subsection{Research Methodology}

This study is purely an investigative one, and it will require survey design. The population of this study is consumers of alcoholic beverages in Aguata L.G.A. A sample size 138 was determined using the Topman formular .This study employed quota sampling technique. This entails that respondents from various demographic characteristics are involved in the sample. A well-structured questionnaire was adapted for this study this is because of the survey design of the study. It comprises of open-ended and closed-ended questions. The closed ended questions were designed using a 5-point Likert scaling ranging from strongly disagree to strongly agree. Pearson Correlation Coefficient was used to test the significance of the hypotheses generated for the study. The study adopted a face and content validity in which copies of the questionnaires were given to experts, supervisor and also to similar respondent used in this research. Reliability on the other hand is the consistency of the test in measuring 
whatever it purports to measure. The reliability analysis for this research was carried out using Cronbach's Alpha Coefficient. The result of the correlation coefficient indicates (0.76).

\subsection{Data Presentation and Analysis}

\subsection{Data Presentation}

The instrument used of the study is questionnaire. Out of 138 questionnaire distributed, 115 $(83 \%)$ were returned as dully filled and usable questionnaire.

\subsection{Demographic Characteristics of the Respondents}

Table: 1 Demographic Characteristics of the respondents

\begin{tabular}{|l|l|l|}
\hline Category & Frequency & Percentage \% \\
\hline Gender & & \\
Male & 74 & 64 \\
Female & 41 & 36 \\
\hline Age & & \\
$21-30$ years & 35 & 30 \\
$31-40$ years & 47 & 41 \\
$41-50$ years & 15 & 13 \\
$51-$ and above & 18 & 16 \\
\hline Marital Status & & \\
Single & 69 & 60 \\
Married & 46 & 40 \\
\hline Educational Qualification & & 16 \\
O'level & 18 & 20 \\
WAEC & 23 & 64 \\
HND/B.Sc & 74 & \\
\hline
\end{tabular}

Table 4.1 shows that $74(64 \%)$ of the respondents are males while $41(36 \%)$ are males. The age category of 21-30 represented 30\%, 31-40 years of the respondents are (41\%), and 41-50 are $13 \%$ while 51 and above are $16 \%$. Marital status shows that the single are $60 \%$ and married $40 \%$. Educational qualification shows that those with O'level represented $16 \%$, WAEC $20 \%$ and HND/B.Sc.represented 64\%.

\subsection{Interpretation of Multiple Regression Analysis}

Multiple regression analysis was carried out to test the hypotheses and the results were presented in the table below:

Table: 2 Model Summaries

\begin{tabular}{|l|l|l|l|l|l|}
\hline Model & $\mathrm{R}$ & $\mathrm{R}$ square & $\begin{array}{l}\text { Adjusted R } \\
\text { square }\end{array}$ & $\begin{array}{l}\text { Std. Error of } \\
\text { the Estimate }\end{array}$ & $\begin{array}{l}\text { Durbin- } \\
\text { Watson }\end{array}$ \\
\hline 1 & $.667^{\mathrm{a}}$ & .718 & .603 & 1.11069 & 1.027 \\
\hline
\end{tabular}

a. Predictors; (Constant) price pack, Contest, coupons

b. Dependent Variables; Customer patronage

The table above shows the model summary of the regression analysis. From the table coefficient of correlation, $\mathrm{R}$ is .667 which is a strong positive correlation. The $\mathrm{R}$ square tells how much of the variance in the independent variables is explained by the model. The value is .718. Adjusted $\mathrm{R}$ square value provides a better estimate of the true population value. The value is .603 which indicates that the numbers of the independent variables and sample size of this study are large enough for a study of his magnitude. 
Table 3 Anova

\begin{tabular}{|l|l|l|l|l|l|}
\hline Model & $\begin{array}{l}\text { Sum of } \\
\text { Squares }\end{array}$ & Df & Mean squre & F & Sig \\
\hline $\begin{array}{l}\text { Regression } \\
\text { Residual }\end{array}$ & 301.110 & 3 & 160.912 & 1115.065 & $.000 \mathrm{~b}$ \\
Total & 109.020 & 112 & .1 .324 & & \\
\hline
\end{tabular}

a. Dependent variable; ${ }^{\text {customer }}$ patronage

b. Predictor; (Constan) price pack, contest, and coupons.

This analysis of variance (ANOVA) table above shows the value of 115.065 and it is statistically significant at .000 . This implies that the regression is statistically different from 1 and further shows that the model is a good fit.

Table 4: Co-efficient

\begin{tabular}{|l|l|l|l|l|l|}
\hline \multirow{2}{*}{ Model } & Unstandardized & Coefficients & Standardized & $\mathrm{T}$ & Sig \\
\cline { 2 - 6 } & $\mathrm{B}$ & Std. Error & Beta & $\mathrm{B}$ & \\
\hline Constant & .313 & .357 & & & \\
Price pack & .355 & .049 & .378 & 3.702 & .001 \\
Contest & .323 & .109 & .256 & 2.541 & .004 \\
coupons & .243 & .104 & .248 & 2.944 & .003 \\
\hline
\end{tabular}

a. Dependent variable; customer patronage

The smaller the value of significance ( $\mathrm{p}$-value), and the larger the $\mathrm{t}$-value, the greater the contribution of that predictor: In this model, price pack $(\mathrm{t}=3.702, \mathrm{p}=001<0.05)$, Contest $(\mathrm{t}=2.541, \mathrm{p}=.004<0.05)$, Coupons $(\mathrm{t}=2.944, \mathrm{p}=.003<0.05)$.

\subsection{Hypothesis Testing}

Hypothesis $\mathbf{H}_{1}$ : The first alternative hypothesis which states that there is a significant effect of price pack on customer patronage of alcoholic beverages. From the regression analysis $(\mathrm{t}=3.7-2, \mathrm{p}=.001<0.05)$. We accept the alternative hypothesis that price pack has a significant effect on customer patronage of alcoholic beverages.

Hypothesis $\mathbf{H}_{2}$ : The second hypothesis is that there is a significant effect of contest on customer patronage of alcoholic beverages. From the regression analysis $(t=2.541, \mathrm{p}=.004$ $<0.05$ ), we accept the alternative hypothesis that contest has a significant effect on customer patronage of alcoholic beverages.

\subsection{Discussion of the Findings}

The study revealed that sales promotions in India are effective measures for inducing brand switching, stock piling and purchase acceleration. Also is in consonance with Mbaga (2016) who asserted that sales promotion tools have a huge impact on consumer patronage behaviour during any competition. However, the results are contrary to the findings by Mkanda (2009) who analyzed the consumer buying behaviours of carbonated soft drinks in the Tanzania market. Five hypotheses were empirically tested and the results showed that there is a significant relationship between the price of the pack and the choice of brand of carbonated soft drinks. Regarding quality the results revealed that the perceived quality of the product negatively influenced the decision of purchase a carbonated soft drinks brand. The negative correlation might result from the fact that consumers often judge the quality of the products on the basis of variety of information cues that they associate with products. 


\subsection{Conclusion}

Based on the findings of the study, the following conclusions were drawn; sales promotion plays a vital role in promoting the brewery industry, especially these that product alcoholic beverages. Most benefits derived by companies engaging in sales promotion are: It helps organizations increase their turnovers, expands the awareness of the company's product, increase sales of a product and made the company go global.

\subsection{Recommendations}

Based on the result of the study and conclusions, the following recommendations are provided:

In as much sales promotion is a key element in the advancement of the brewery industry, tools selected should be sustained overtime while being flexible due to economic instability so as to avoid downward fluctuations in their profit margin.

\section{References}

1. Aderemi, K (2013). The dimensionality of consumption emotion pattern and consumer satisfaction. Journal of Consumer Research, 18, 84-91.

2. Agbonifoh, B.A, Nnoli. D.A \& Knamnebe A.D (2007) Marketing in Nigeria Concepts, principles \& decisions, 2nd Ed. Aba: A.fritowers Limited.

3. Ailawadi K, Beauchamp JP, Donthu N, Gauri DK, Shankar V (2009) A path Analytic Model of store Loyalty involving self-concept. Stone Image, Socioeconomic status, and Geographic Loyalty. "Journal of the Academy of Marketing Science. 13: 265-91.

4. Ailawadi, K and Joseph, A.C (2009) A path Analytic Model of Store Loyalty Involving.

5. Armstrong, G. Education, Inc \& Kotler, P. (2005) Marketing: An introduction. new Jersey: Pearson

6. Berkowitz, Kerin, Hartley and Rudelius, (2000) The dimensionality of consumption emotion pattern and consumer satisfaction. Journal of Consumer Research, 18, 84-91.

7. Blattberg, $\mathrm{H}$ and Neslin, $\mathrm{H}$ (2009) The development of utility theory: Journal of Books. Bottle of wine. International Journal of Wine Marketing, 18 (3), 218- 232.

8. Bloone P N \& Kurtz (2004) "Deregulation's challenges for Marketers in Readings in Marketing management. A strategic perspective (1984) edited by Barry Berman and Joel R. Evans, New York: John Wiley and sons.

9. Clow, K.E., and Baack, D., (2007) Integrated Advertising, promotions, and Marketing Communications. Global Edition. Pearson Prentice Hall., United States of America. Hair, Control, Translated by Bahman Frozandeh, Atropat publications, 1st publication, Esfahan.

10. Czinkota, N and Brassington, F (2001) principles of Marketing, 3rd Edition,Pearson Education, Prentice Hall.

11. Dhar and Hoch, Dreze and Purk, (1994) Strategic Brand Management Process, in perspective of Modern Brand management, Ed. Dr. Franz-Rudolf Esch.

12. Dick, A. \& Basu K (1994). Customer loyalty: toward and integrated conceptual framework. Jurnal of Academy of marketing services, vol.22 (2), p.p 99-113 DOI: 10.1177/0092070394222001.

13. Drucker, H (1973). Packaging as a tool for product development: Communicating value.

14. Ehrenberg, A.S.C., Hammond, K \& Goodhardt, G.J (1994), The after-effects of price related consumer electronics products, delft university of technology. Elements of consumers purchasing Decisions. International” Business and empirical evidence. Corporate Communications: An International Journal II.

15. Esfahani AN, Jafarzadeh M. (2012) Studying impacts of sales promotion on consumer's psychographic variables. Essex. 
16. Forbes, T (2011). Product satisfaction as a function of Expectation and Performance, "in Consumer satisfaction, Dissatisfaction and Complaining. $36-41$.

17. Frozandeh, Aokhteh publication, 5th publication.

18. Gardener E, Trivedi M. (2016), A communication framework to evaluate sales promotion strategies. J. Advert.

19. Gilbert, D. and Jackaria, N (2012)."The efficacy of sales promotions in UK super markets: a consumer view". International Journal of Retail \& Distribution Management, 35 (9), 677-690.

20. Jordaan, R and Van Heeden, G (2010) The verbal and visual components of package design. Journal of product Brand Management, 9 (1), 56-70. Journal of the Academy of Marketing Science. 13: 265-91.

21. Kotler P, Keller P.J (2006) B2B Brand Management. Heidelberg: Springer.

22. Kotler P. Keller P.J (2012), Marketing Management. Delhi: Pearson Education. Kumar SR (2007) Marketing and Branding.

23. Kotler, P (2009) Marketing management: analysis, planning, implementation and

24. Kotler, P. Armstrong, G (2006), Marketing principles, translated by Bahman

25. Kotler, P and Armstrong G. (2010) "principle of Marketing", 13 edition: Pearson Education International. Printed in upper Saddle River, New Jersey.

26. Kotler, P. and Keller, K.L (2014) Marketing Management (14th Ed) Essex: Pearson Education Limited.

27. Kwame, K 92013) Packaging communication: Attentional effects of product imagery. Journal of product \& Brand Management, 10 (7), 403- 422.logistics, 17(1):32-49.

28. Mbaga, M.H 92016) A Research Proposal Submitted in Partial Fulfillment of the Requirements for the Degree of Master of Business Management (MBA- CORPORATE MANAGEMENT).

29. Mboma, (2007) Motivational factors of gender, income and age on selecting a bottle of wine. International Journal of Wine Marketing, 18 (3), 218-232.

30. Mela, C.F, Gupta, S. \& Lehma, D.R (2007) The long term impact of promotional and advertising on consumer brand choice. Journal of Marketing Research,34(May).

31. Mettal, B \& Lasser, W.M (2011) The role of personalization in service encounters. Journal of Retailing, 72 (1).

32. Mkanda, M 92009) The role of packaging in positioning an orange juice. Journal of food mobile phone market: The Nigerian Experience. Business Intelligence Journal, Model. Elect mark 11;17-25

33. Moriarty R and Wever, B (2012) Sales performance of packaging for consumer electronics products, delft university of technology.

34. Moshi, N (2009) The importance of packaging design for own-label food brands.Mzumbe university.

35. Ndubuisi O.N (2005), Customer Behavioural Responses to Sales promotion: The Role of Fear of Losing Face, Asian Pacific Journal of marketing.

36. Ndubuisi N.O, and Chew, T.M (2006) Awareness and Usage of promotional tools by Malaysian Consumers: the case of low involvement products. Management.

37. Ogwo, O.E \& Igwe, S.R (2012) Some keys factors influencing Attitudes to patronage of GSM services: The Nigerian experience. International Journal of Management, vol.7 (18), pp. 82-91. DOI: 10.5539/ijibm.vtn18 p 82.

38. Okeke, T.C, Olise M. \& Eze G.A (2012) Research Methods in Business and Management Science. (2nd edition), Enugu, Iyke Venture productions.

39. Olive, T.A Olive R.L \& Macmilan, I.C (1992) A catastrophe model for developing service satisfaction strategies. Journal of marketing. Vol.56, pp.183-193.DOI: $102307 / 1252298$. 
40. Oliver, R.L (1999) Whence customer loyalty. Journal of Marketing, 63 (special on perceived service quality", Advances in Consumer Research, Vol. 22 No. 1, pp. 58-61.

41. Oliver, R.L (1997) Satisfaction: A Behavioural perspective on the Consumer.Boston, McGraw-Hill.

42. Olannye, A.P (2006) Research Method for Business; a skill building approach,lagos; pee Jem publication.

43. Oliver, R.L (1999) whence Consumer Loyalty. Journal of Marketing 63 (Special edition) 33-34

44. Onyeizugbe C.U (2013) Practical Guide to Research Methodology in Management,Onitsha; Good success press@ 5 Ven Rd, North.

45. Oyeniyi J.O \& Abiodun J.A (2009), Switching Cost and Customer Loyalty in the Mobile Phone Market: The Nigerian Experience. Business Intelligence Journal, pp 111-121. Pp. 248-261.

46. Pride, M.W and Farrell O.C (2008), Marketing basic Concepts and Decisions: Houghton Mifflin Company. Proceedings, Winter Conference, American Marketing Association, (1964), 200 Research News, 29(1/2):28-40.

47. Ripon, M and O'Cass (2007) Fashion Clothing Consumption: Consequences of fashion clothing involvement: European Journal of Marketing, 38,7,869-882.

48. Schiffman, L.G, Kanuk, L.L (2007). Purchasing Behaviour (9th ed) Upper Saddle.

49. Schultz (2009) Product symbolism and the perception of Social Strata," and Geographic Loyalty." Product Symbolism and the Perception of social Strata," Self Concept. Store Image, Socioeconomic status, and Geographic Loyalty."

50. Sheth, J.N (1983). An Integrative theory of patronage preference and behaviour. In Darden, W.F and R.F Lusch (eds) patronage behaviours and retail management. New York. North-Holland pp 9-28.

51. Sheth, J.N.B.I and Newman B.L Gross, B.l (1991) Why We Buy What we Buy a Theory of Consumer behavior. Journal of Business Research Vol 22. 159- 170.

52. Shimp T A (2010) Advertising promotion and Supplemental Aspects of Integral marketing communications, $7 \mathrm{t}$ ed. Mason: South Western Cengage Learning.

53. Sinha, I. and Smith, M.F (2000) "Consumers perceptions of promotional framing of price" Psychology to consumers: Journal of Food Distribution Research, 38 (1), 61-66. 